\title{
The Big Fish-Little Pond Effect on Affective Factors Based on PISA 2012 Mathematics Achievement
}

\section{PISA 2012 Matematik Başarısına Dayalı Duyuşsal Faktörlerde Büyük Balık-Küçük Göl Etkisi}

\author{
Dilara BAKAN KALAYCIOĞLU*
}

\begin{abstract}
In this study, the 2012 PISA Turkey student questionnaire data is considered to determine the big fish-little pond effect. The mathematics self-efficacy, self-concept and anxiety affective factors are examined to explain the relation of each of them with the school type, gender, socioeconomic status, student's mathematics achievement and school's mathematics achievement covariates. A total number of 771 students from 88 high schools are in the sample. Factor analyses' results support the construct validity of the Student Questionnaire's mathematics self-efficacy, anxiety and self-concept items. Data set is analyzed with Multiple Indicator Multiple Cause Model and the patterns of association with covariates and affective factors were tested simultaneously. According to the results, Anatolian high school students have a higher mathematics selfefficacy and lower mathematics anxiety than do the general high school students. However, when the student mathematics achievement and school mathematics achievement variables were inserted to the model, school type was not associated with mathematics self-efficacy. Moreover, Anatolian high school student's mathematics anxiety was higher than that of the general high school students. Student's mathematics achievement was the most significant predictor of the mathematics self-efficacy, anxiety and self-concept factors. Finally, school's mathematics achievement was a significant predictor of only mathematics selfconcept. The identification of increase in school's mathematics achievement yields a decrease in the student's mathematics self-concept may be considered as the most important result of this study. These results provide evidence about the Anatolian high schools' students experience big fish-little pond effect.
\end{abstract}

Keywords: Big fish-little pond effect, mathematics self-efficacy, anxiety, self-concept

$\ddot{O} z$

Bu çalışmada, PISA 2012 Türkiye öğrenci anketi kullanılarak büyük balık-küçük göl etkisi belirlenmeye çalışılmıştır. Matematik dersine yönelik öz-yeterlik, benlik ve kaygı duyuşsal faktörlerinin okul türü, cinsiyet, sosyoekonomik statü, öğrenci matematik başarısı ve okul matematik başarısı değişkenleri ile arasındaki ilişkiler incelenmiş̧tir. Örneklemde 88 liseden 771 öğrenci bulunmaktadır. Açımlayıcı ve doğrulayıcı faktör analizi sonuçları öğrenci anketindeki matematik öz-yeterlik, benlik ve kaygı maddelerinin yapı geçerliğini desteklemektedir. Analizler, Çoklu Gösterge ve Çoklu Neden Modeli ile gerçekleştirilmiş ve model yardımıyla neden değişkenleriyle, duyuşsal faktörler arasındaki ilişki örüntüleri aynı anda kestirilmiştir. Sonuçlara göre, Anadolu lisesi öğrencileri genel lise öğrencilerinden daha yüksek matematik öz-yeterlik algısına ve daha düşük matematik kaygısına sahiptir. Ancak, modele öğrenci matematik başarısı ve okul matematik başarısı değişkenleri de eklendiğinde, okul türü matematik öz-yeterliği ile ilişkili değildir. Ayrıca, Anadolu lisesi öğrencilerinin matematik kaygısının genel lise öğrencilerinden daha yüksek olduğu belirlenmiştir. Matematik öz-yeterlik, benlik ve kaygı değişkenlerinin en güçlü tahmin edicisi, öğrenci matematik başarısıdır. Son olarak, okul matematik başarısı sadece matematik benlik algısının istatistiksel olarak anlamlı bir tahmin edicisidir. $\mathrm{Bu}$ çalışmanın en önemli bulgusu, okul matematik başarı ortalaması arttıkça öğrencilerin matematik benlik algılarının düşme eğiliminde olduğunun belirlenmesidir. Bu sonuçlar, büyük balık-küçük göl etkisinin Anadolu lisesi öğrencileri tarafından yaşandığına dair kanıt sunmaktadır.

Anahtar Kelimeler: Büyük balık-küçük göl etkisi, matematik öz-yeterlik, kaygı, benlik * Dr., Ölçme Seçme ve Yerleştirme Merkezi, Soru Hazırlama ve Geliştirme Daire Başkanlığı, Ankara-Türkiye, e-posta:
dilara.bakan @ osym.gov.tr

Eğitimde ve Psikolojide Ölçme ve Değerlendirme Dergisi, Cilt 8, Sayı 1, İlkbahar 2017, 1-14.

Journal of Measurement and Evaluation in Education and Psychology, Vol. 8, Issue 1, Spring 2017, 1-14. 


\section{INTRODUCTION}

Relationship between affective factors and academic achievement is one of the most widely studied subjects in the literature. There is a reciprocal relationship between affective factors and academic achievement (Marsh, Hau, Artelt, Baumert \& Peschar, 2006; Marsh, Trautwein, Lüdtke, Köller \& Baumert, 2005). According to the social cognitive theory, self-efficacy is defined as the perception of one's own ability to complete tasks and reach goals (Bandura, 1993), which is one of these affective factors. Self-concept is another affective factor that is described as the students' beliefs about themselves that include own knowledge, value, abilities and aims (Hattie, 1992). Thus, mathematics self-concept is defined as the student's beliefs in their perception of being successful at mathematics and their confidence as mathematics learners (Reyes, 1984; Wilkins, 2004). Contrary to self-concept, mathematics anxiety is the feeling of helplessness and stressful when dealing with mathematics (Ashcraft, 2002; Hembree, 1990). Different studies show that self-efficacy and selfconcept are positively (Alc1, Erden \& Baykal, 2010; Chiu \& Xihua, 2008; İş Güzel \& Berberoğlu, 2010; Hammouri, 2010; Özel, Çağlak \& Erdoğan, 2012; Wilkins, Zembylas \& Travers, 2002), and anxiety is negatively related to students' academic performance (Cassady \& Johnson, 2002; Ho et al., 2000; Ma, 1999; McCarthy \& Goffin, 2005; Seipp, 1991).

Gender and socioeconomic status are also influential variables on students' affective factors. It was shown that generally male students' mathematics self-efficacy (Bong, 1998; Özgen \& Bindak; 2011; Pajares, 1996; Taşdemir, 2012) and mathematics self-concept (Pajares \& Miller; 1994) are higher than that of female students'. When the relationship between mathematics anxiety and gender is discussed, some research studies show that female students have more anxiety than do the male students (Baloglu \& Kocak, 2006; Hembree, 1990; Jain \& Dowson, 2009; Wigfield \& Meece, 1988) whereas other studies indicate that there is no significant difference between the gender and the mathematics anxiety (Cooper \& Robinson, 1989; Pajares \& Graham, 1999; Kurbanoğlu \& Takunyac1, 2012). Some authors show that students with higher socioeconomic status have higher mathematics self-efficacy and self-concept perception than do the students with lower economic status (Marsh et al., 2006) and these students also have a lower mathematics anxiety than do the students with lower socioeconomic status (Geist, 2010).

In addition to the mentioned variables above, the social comparison environment can also influence the affective factors. According to the social comparison theory, people evaluate their opinions and abilities by comparing themselves with other people around their environment (Festinger, 1954). Therefore, schools are one of these social comparison environments that influence our selfevaluation. The effect of social comparison, especially on the self-concept, is well-known (Wood, 1989). In the literature, there are evidences about the negative impacts of academically successful student's getting education with the similar level of students on the self-concept perception (Marsh, Trautwein, Lüdtke, Baumert \& Köller, 2007). The students who do grouped according to their academic capabilities have lower self-concept perception than the similar students who are at a combined talent level school (Nagengast \& Marsh, 2011), which is generally called as big fish-little pond effect. Big fish-little pond effect is especially encountered at the education systems where the students are grouped according to their academic success (Ho, 2009). Big fish-little pond effect was also shown in the studies performed by the data of Germany (Marsh, Köller \& Baumert, 2001), Hong Kong (Marsh, Kong \& Hau, 2000), Israel (Zeidner \& Schleyer, 1999), and Australia (Marsh, Chessor, Craven \& Roche, 1995). Altun and Yazic1 (2013) also explain the higher self-concept perception of vocational, general and Anatolian high school students than that of the science high school students with the big fish-little pond effect.

On the other hand, in general, the studies about self-efficacy and anxiety show that the students with high ability levels have higher mathematics self-efficacy than do the students with the low ability levels (Pajares \& Graham, 1999). In Turkey, Anatolian high school student's mathematics selfefficacy is higher than that of the general high school students (Kurbanoğlu \& Takunyac1, 2012; Özgen \& Bindak, 2011) whereas their anxiety levels are lower than that of the general high school students (Kurbanoğlu \& Takunyac1, 2012). 
In Turkey, there was a centralized multiple-choice examination for the student selection to the high schools except the general high schools in 2012. While the students who are admitted to the Anatolian high schools compare themselves with the similar ability level students, the general high school students usually have the chance to compare themselves with a high range of different ability level students. Thus, the social comparison environment changes according to the school types. Since the students are grouped according to their academic achievement in Turkey, the influence of big fish-little pond effect is encountered at the school level. Thus, it is believed that the student's awareness affects their perception of mathematics self-efficacy, anxiety and self-concept.

There are many studies about the relation of the socioeconomic status, school type, gender and student's mathematics achievement with the mathematics self-efficacy, anxiety and self-concept. To the best knowledge of author, there is not any study that considers the school's mathematics achievement with these mentioned variables and the effects of big fish-little pond on the student's mathematics self-efficacy, anxiety and self-concept for Turkish data.

In this study, the 2012 data of Programme for International Student Assessment (PISA), for Turkey is considered to determine the big fish-little pond effect for Anatolian high school students and general high school students. Thus, the mathematics self-efficacy, self-concept and anxiety factors are examined to explain the relation of each of them with the gender, socioeconomic status, student mathematics achievement, and school mathematics achievement. The aim of this study is to find answers to the following questions.

1. Are there any statistical difference between the Anatolian and general high school students' mathematics self-efficacy, anxiety and self-concept in terms of school type, gender and socioeconomic status?

2. Are there any statistical difference between the Anatolian and general high school students' mathematics self-efficacy, anxiety and self-concept in terms of school type, gender and socioeconomic status, mathematics achievement and school's mathematics achievement?

\section{METHOD}

In this study, PISA 2012 Turkish data set is analyzed with MIMIC (Multiple Indicator Multiple Cause) model which is a special case of structural equation modeling. MIMIC model consists of two parts; a measurement model which defines the relations between a latent variable and its indicators and a structural model which specifies causal relationships among latent variables and explains the causes (covariates) (Jöreskog \& Sörbom, 1996). In measurement model, latent variables are defined by observable indicator variables. Latent variables of this study are mathematics self-efficacy, anxiety, self-concept; observable indicator variables are PISA student questionnaire items; covariates are school type, gender, socioeconomic status, student mathematics achievement and school mathematics achievement. MIMIC modeling was used in order to assess the effect of covariates on the mentioned three affective factors. MIMIC model provides simultaneous detection of association between the covariates and latent variables and it also indicates the unique effects of each covariate after controlling for the effects of the other covariates.

\section{Sample}

The data analyzed in this research were obtained from the PISA 2012 assessment. The target population of PISA 2012 was fifteen years old students. 4848 students from Turkey are participated in PISA 2012. PISA employed two-stage sampling procedure to ensure that a representative sample of target population for each country (OECD, 2013). Different students take different combinations of items and student questionnaire. We only consider students who completed the mathematics selfefficacy, anxiety and self-concept scales in Turkish data set. A total number of 771 students (423 females, 348 males) from 88 high schools (36 Anatolian and 52 general high schools) are in the 
sample. Among these students, 333 of them are (42\%) Anatolian high school and 438 (58\%) of them are general high school students. The missing values were replaced by mean values of the variables.

\section{Measures}

The data set were acquired from the official website of OECD. The PISA 2012 study consisted of achievement tests along with a student questionnaire, a teacher questionnaire and a school principal questionnaire. In th's present study, items from the student questionnaire associated with school type, gender, socioeconomic status, self-efficacy, anxiety and self-concept are used. These items are explicitly described below.

Anatolian and general high schools are the two types of high schools considered in this study. Anatolian high schools are public schools that admit their students according to high stake nationwide standardized examination. General high schools are also public schools but that admit students without examination. The PISA code of the Anatolian high schools is 07920002, which is coded as 1 whereas the PISA code of the general high schools is 07920003, which is coded as 0. Male and female students are coded as 1 and 0 , respectively.

Socioeconomic status (SES) in PISA is assessed by educational, social and cultural status (ESCS) index. ESCS index is a composite index of three separate indexes: highest parental education, highest parental occupation, and cultural economic resources. The index maintains a mean of 0 and a standard deviation of 1 for students from OECD countries (OECD, 2013).

PISA aims to measure students' ability to handle certain mathematics processes originating from a real world context. Mathematics achievement test contains four content categories: quantity, uncertainty and data, change and relationship, space and shape. Some questions are multiple choice and others require students to construct their response. Since the PISA assessment used incomplete assessment design, students are required to answer a subset of the item battery; PISA estimates students' test scores as plausible values with each student having five plausible values for mathematics performance. Plausible values represent the range of abilities that a student might reasonably have based on student responses to the subset of items they receive, as well as on other relevant and available background information (Wu \& Adams, 2002). PISA calculated mathematics achievement scores of students with a mean of 500 and standard deviation of 100 . Students' mathematics achievement scores (five plausible values) are converted to $\mathrm{z}$ scores. A separate data analyses with mathematics achievements was run for each plausible value (PV1MATH-PV5MATH) and in order to provide unbiased estimates, the results are averaged according to the OECD (2009) protocols. School mathematics achievement scores are calculated with the school's students' mathematics achievement mean scores and then these scores are converted to $\mathrm{z}$ scores.

Mathematics self-efficacy items asked students to report on their confidence in doing a range of mathematical tasks with an example is using a 4-point agreement scale. Students' responded eight items, whether they feel "very confident", "confident", "not very confident" and "not at all confident". The highest response code was indicative of a positive rating of self-efficacy.

Mathematics anxiety items include five statements and asked students to report what extent they are agreed to given statements is using a 4-point agreement scale. Responses are ranged between "strongly agree", "agree", "disagree" and "strongly disagree". Similar to previous scale, the highest response code was indicative of a positive rating of mathematics anxiety.

Mathematics self-concept items include five statements and asked students to report what extent they are agreed to given statements is using a 4-point agreement scale (OECD, 2013). Responses are ranged between "strongly agree", "agree", "disagree" and "strongly disagree". 


\section{Analysis of Data}

In order to examine factor structure, the selected items were subjected to Exploratory Factor Analysis (EFA). Based on factor analysis results, items which loaded different factors for the different school type is excluded from analysis. Thus, four of the original 18 items were not considered for further EFA. Cronbach's alpha $(\alpha)$ correlation coefficient value was also calculated for each factor using reliability analysis. Prior to the insertion of the covariates, Confirmatory Factor Analysis (CFA) were performed to evaluate construct validity of measurement model. Then, MIMIC model applied to compare path coefficients of Anatolian and general high schools.

The indices used to test goodness of model fit are RMSEA (Root Mean Square Error of Approximation), CFI (Comparative Fit Index), NFI (Normed Fit Index) and GFI (Goodness of Fit Index). Lower than .05 RMSEA value indicates excellent fit; the RMSEA value around .08 indicates adequate fit. Larger than .95 of CFI, NFI, GFI values reflect a good fit (Hu \& Bentler, 1998; Schumacker \& Lomax, 2010). $\chi^{2}$ test statistics is directly affected by sample size and for large samples trivial differences may become significant. $\chi^{2}$ test statistics are also provided but due to its sensitivity to sample size to assess model fit, RMSEA, CFI, NFI and GFI fit indices are interpreted. (Browne \& Cudeck, 1993; Wu, Li, \& Zumbo, 2007).

All analyses reported in this study are carried out using LISREL 8.80 for Windows (Jöreskog \& Sörbom, 2006) with SIMPLIS command language. Since the mathematics self-efficacy, anxiety and self-concept items are categorical, WLS (Weighted Least Square) estimation method is used in confirmatory factor analysis and RML (Robust Maximum Likelihood) estimation method is used in MIMIC models analyses.

\section{RESULTS}

Means and standard deviations of variables for different school types are presented in Table 1.

Table 1. Means and Standard Deviations of Variables for Different School Types

\begin{tabular}{|c|c|c|c|c|c|c|c|c|c|c|c|c|}
\hline \multirow[t]{2}{*}{ School type } & \multicolumn{2}{|l|}{ SES } & \multicolumn{2}{|c|}{$\begin{array}{l}\text { Student } \\
\text { mathematics } \\
\text { achievement }\end{array}$} & \multicolumn{2}{|c|}{$\begin{array}{l}\text { School } \\
\text { mathematics } \\
\text { achievement }\end{array}$} & \multicolumn{2}{|c|}{$\begin{array}{l}\text { Mathematics } \\
\text { self-efficacy }\end{array}$} & \multicolumn{2}{|c|}{$\begin{array}{l}\text { Mathematics } \\
\text { anxiety }\end{array}$} & \multicolumn{2}{|c|}{$\begin{array}{l}\text { Mathematics } \\
\text { self-concept }\end{array}$} \\
\hline & $\overline{\bar{X}}$ & $s d$ & $\overline{\bar{X}}$ & $s d$ & $\overline{\bar{X}}$ & $s d$ & $\overline{\bar{X}}$ & $s d$ & $\overline{\bar{X}}$ & $s d$ & $\overline{\bar{X}}$ & $s d$ \\
\hline General & -1.68 & .48 & 414.80 & 63.46 & 412.08 & 55.04 & 17.68 & 3.37 & 10.27 & 2.93 & 9.63 & 3.18 \\
\hline Anatolian & -.82 & .64 & 530.11 & 70.04 & 521.55 & 48.54 & 19.29 & 3.08 & 9.59 & 2.87 & 9.88 & 3.02 \\
\hline
\end{tabular}

As given in Table 1, Anatolian high school students' means are higher than that of the general high school students for all variables except mathematics anxiety. The correlations between variables are presented in Table 2.

Table 2. Correlations between Variables

\begin{tabular}{|c|c|c|c|c|c|c|c|c|}
\hline Variables & 1 & 2 & 3 & 4 & 5 & 6 & 7 & 8 \\
\hline 1. School type & 1 & & & & & & & \\
\hline 2. Gender & -.03 & 1 & & & & & & \\
\hline 3. SES & $.38^{*}$ & .01 & 1 & & & & & \\
\hline 4. Student mathematics achievement & $.66^{*}$ & .07 & $.41^{*}$ & 1 & & & & \\
\hline 5. School mathematics achievement & $.78^{*}$ & -.03 & $.47^{*}$ & $.81^{*}$ & 1 & & & \\
\hline 6. Mathematics self-efficacy & $.24^{*}$ & $.16^{*}$ & $.23^{*}$ & $.40^{*}$ & $.32^{*}$ & 1 & & \\
\hline 7. Mathematics anxiety & $-.11^{*}$ & .02 & $-.10^{*}$ & $-.28^{*}$ & $-.18^{*}$ & $-.23^{*}$ & 1 & \\
\hline 8. Mathematics self-concept & .04 & .08 & $.10^{*}$ & $.21^{*}$ & .08 & $.42^{*}$ & $-.52^{*}$ & 1 \\
\hline
\end{tabular}

Note. $\mathrm{N}=771 .{ }^{*} p<.01$. 
Correlation between the variables showed wide range of values indicating varying levels of strength of associations. Patterns of correlation were generally within the theoretical expectations. As can be seen in Table 2, the highest correlation value of .81 is between mathematics achievement and school mathematics achievement. The highest negative correlation value of -.52 is between mathematics anxiety and mathematics self-concept.

In the first step, the principal axis factoring with items from the student questionnaire associated with Varimax rotation method was used to examine the underlying structure of the data. The factor loadings from EFA presented in Table 3.

Table 3. Factor Loadings of the Exploratory Factor Analysis with Varimax Rotation

\begin{tabular}{|c|c|c|c|}
\hline \multirow{2}{*}{ Items } & \multicolumn{3}{|c|}{ Factor } \\
\hline & 1 & 2 & 3 \\
\hline \multicolumn{4}{|l|}{ Mathematics self-concept } \\
\hline St42Q07. I have always believed that mathematics is one of my best subjects. & .76 & .20 & -.25 \\
\hline St42Q06. I learn mathematics quickly. & .70 & .25 & -.29 \\
\hline St42Q04. I get good marks in mathematics. & .68 & .17 & -.25 \\
\hline St42Q09. In my mathematic class. I understand even the most difficult work. & .67 & .26 & -.18 \\
\hline \multicolumn{4}{|l|}{ Mathematics self-efficacy } \\
\hline St37Q02. Calculating how much cheaper a TV would be after a $30 \%$ discount & .07 & .70 & -.11 \\
\hline $\begin{array}{l}\text { St37Q01. Using a train timetable to work out how long it would take to get from one place } \\
\text { another }\end{array}$ & to. 10 & .64 & -.05 \\
\hline St37Q03. Calculating how many square meters of tiles you need to cover a floor & .24 & .63 & -.09 \\
\hline St37Q08. Calculating petrol consumption rate of a car & .18 & .54 & -.02 \\
\hline St37Q04. Understanding graphs presented in newspapers & .05 & .47 & -.05 \\
\hline St37Q06. Finding the actual distance between two places on a map with a 1:10.000 scale & .19 & .40 & -.08 \\
\hline \multicolumn{4}{|l|}{ Mathematics anxiety } \\
\hline St37Q03. I get very tense when I have to do mathematics homework & -.30 & -.10 & .75 \\
\hline St37Q05. I get very nervous doing mathematics problems & -.09 & -.09 & .71 \\
\hline St37Q08. I feel helpless when doing a mathematics problem & -.19 & -.09 & .68 \\
\hline St37Q01. I often worry that it will be difficult for me in mathematics classes & -.37 & -.06 & .61 \\
\hline
\end{tabular}

Note. ST42Q07 refers to question 42, stem 7 in students' questionnaire.

As given in Table 3, EFA derived three factors, mathematics self-concept, self-efficacy, and anxiety; their corresponding eigen values are 4.88, 2.08 and 1.25, respectively. These factors were named according to the common characteristics of the items loaded on the same factors, and also based on PISA 2012 framework (OECD, 2013). These three factors explained 58.62\% of the total variances. Total variances explained by mathematics self-concept, self-efficacy and anxiety factors are $34.86 \%$, $14.85 \%$ and $8.91 \%$, respectively. Four items loaded on the mathematics self-concept factor $(\alpha=.86)$, six items on mathematics self-efficacy factor $(\alpha=.74)$, and four items on mathematics anxiety factor $(\alpha=.82)$. Factor loadings of items take values between .40 and .76 , which is satisfactory.

In the second step, CFA were carried out to confirm the EFA results. The CFA model for Anatolian high schools yielded a $\chi^{2}(74)=150.10, p<.0001$, RMSEA $=.037$ [.028:.045], CFI=.97, NFI=.95, GFI= .99. Overall model fit seems adequate based on values of selected fit indexes. These results indicated that, the three factors model that emerged in the EFA was confirmed by the CFA.

In the third step, the structural part of the model was inserted to measurement model and the MIMIC model was estimated. The influence of school type, gender, and SES on the mathematics selfefficacy, anxiety and self-concept factors were estimated simultaneously via standardized partial regression coefficients. MIMIC Model 1 results presented in Table 4. 


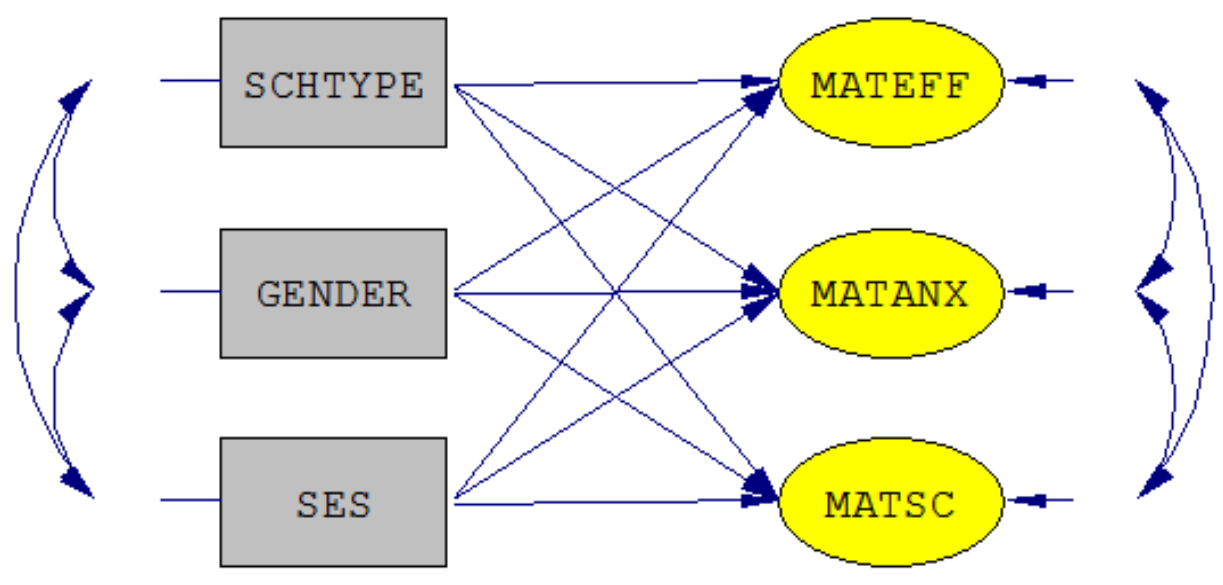

Figure1. MIMIC Model 1

Note. SCHTYPE: school type; GENDER: gender; SES: socioeconomic status; MATEFF: mathematics self-efficacy; MATANX: mathematics anxiety; MATSC: mathematics self-concept.

Table 4. MIMIC Model 1 Results

\begin{tabular}{llllllllll}
\hline & \multicolumn{3}{l}{ Mathematics self-efficacy } & \multicolumn{3}{l}{ Mathematics anxiety } & \multicolumn{3}{c}{ Mathematics self-concept } \\
\hline \multirow{3}{*}{ School type } & $\beta$ & $b$ & $S E$ & $\beta$ & $b$ & $S E$ & $\beta$ & $b$ & $S E$ \\
Sender & $0.23^{*}$ & 0.39 & 0.07 & $-0.09^{*}$ & -0.16 & 0.07 & 0.01 & 0.02 & 0.07 \\
SES & $0.16^{*}$ & 0.27 & 0.06 & 0.01 & 0.02 & 0.07 & $0.09^{*}$ & 0.16 & 0.07 \\
\hline & $0.20^{*}$ & 0.15 & 0.03 & $-0.10^{*}$ & -0.07 & 0.03 & $0.10^{*}$ & 0.08 & 0.03 \\
\hline
\end{tabular}

Note. ${ }^{*} p<0.01$. $\beta$ : standardized path coefficients; $b$ : unstandardized estimates; SE: standard error of estimates.

The MIMIC Model 1 presented in Figure 1 showed adequate fit $\left(\chi^{2}(107)=395.80\right.$; RMSEA $=.059$ $[.052: .063] ; \mathrm{CFI}=.97 ; \mathrm{NFI}=.96 ; \mathrm{GFI}=.93)$. Overall, $16 \%, 2 \%$ and $2 \%$ of the variability of mathematics self-efficacy, anxiety and self-concept factors were explained respectively by this MIMIC model.

MIMIC Model 1 confirms that Anatolian high school students were more likely to have higher mathematics self-efficacy and lower anxiety than do general high school students, while other covariates are controlled in the model. However, school type was not associated with students' mathematics self-concept. According to gender, male students were more likely to have higher mathematics self-efficacy and self-concept compared to female students do have. Gender was not associated with mathematics anxiety. Finally, students with higher SES were more likely to have higher mathematics self-efficacy and self-concept and lower mathematics anxiety compared to students do have from lower SES.

In addition to variables in Model 1, mathematics achievement and school mathematics achievement variables were inserted to Model 2. Table 5 shows the path coefficients for the effects of covariates on mathematics self-efficacy, anxiety and self-concept in the MIMIC Model 2. 


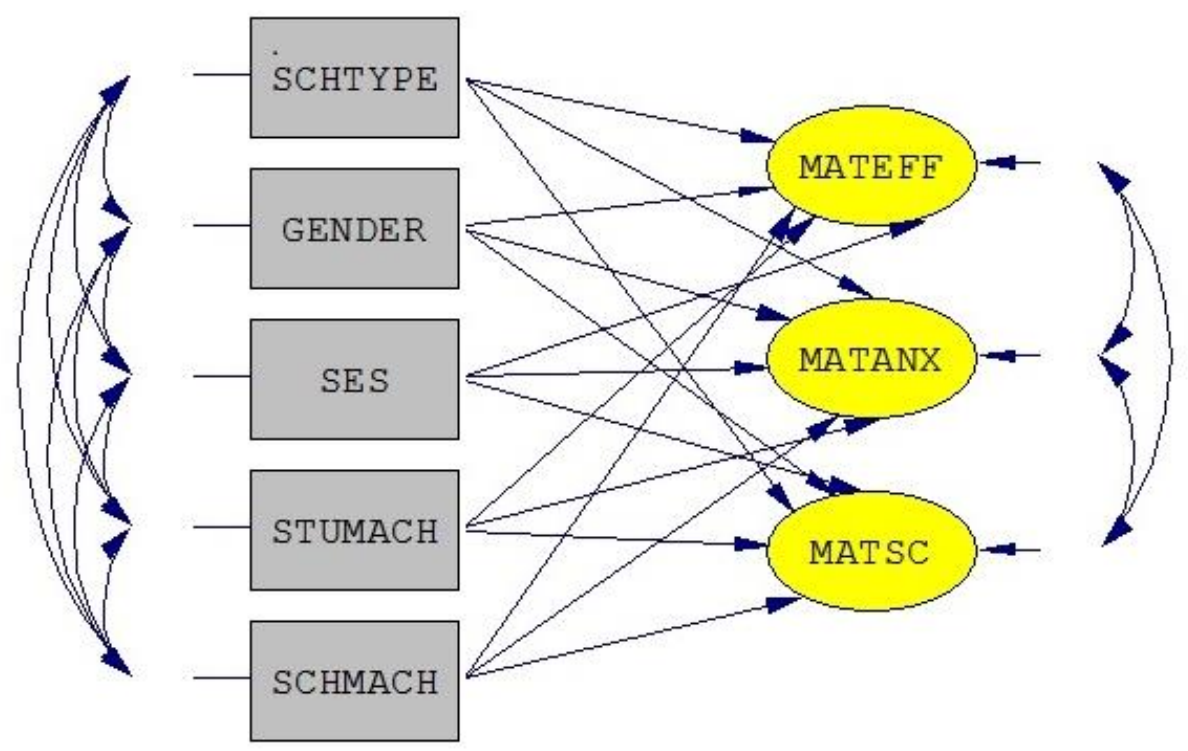

Figure 2. MIMIC Model 2

Note. SCHTYPE: school type; GENDER: gender; SES: socioeconomic status; STUMACH: student mathematics achievement; SCHMACH: school mathematics achievement; MATEFF: mathematics self-efficacy; MATANX: mathematics anxiety; MATSC: mathematics self-concept.

Table 5. MIMIC Model 2 Results

\begin{tabular}{llllllllll}
\hline & \multicolumn{3}{l}{ Mathematics self-efficacy } & \multicolumn{3}{l}{ Mathematics anxiety } & \multicolumn{3}{l}{ Mathematics self-concept } \\
\hline & $\beta$ & $b$ & $S E$ & $\beta$ & $b$ & $S E$ & $\beta$ & $b$ & $S E$ \\
\cline { 2 - 11 } School type & -0.04 & -0.07 & 0.10 & $0.10^{*}$ & 0.19 & 0.12 & -0.09 & -0.17 & 0.11 \\
Gender & $0.13^{*}$ & 0.23 & 0.06 & 0.05 & 0.09 & 0.07 & 0.06 & 0.10 & 0.07 \\
SES & $0.11^{*}$ & 0.08 & 0.03 & -0.03 & -0.02 & 0.03 & 0.06 & 0.04 & 0.03 \\
Student mathematics achievement & $0.40^{*}$ & 0.35 & 0.05 & $-0.47^{*}$ & -0.44 & 0.06 & $0.46^{*}$ & 0.41 & 0.06 \\
School mathematics achievement & 0.07 & 0.06 & 0.07 & 0.12 & 0.11 & 0.08 & $-0.22^{*}$ & -0.20 & 0.07 \\
\hline
\end{tabular}

Note. ${ }^{*} \mathrm{p}<0.01$. $\beta$ :standardized path coefficients; $b$ :unstandardized estimates; $S E$ : standard error of estimates.

Model 2 also showed adequate degree of fit to data $\left(\chi^{2}(129)=455.40\right.$; RMSEA $=.057$ [.052:.063]; $\mathrm{CFI}=.98$; NFI=.97; GFI= .93). Overall, $26 \%, 12 \%, 10 \%$ of the variability of mathematics selfefficacy, anxiety and self-concept factors were explained respectively by MIMIC Model 2.

After controlling the effects of other covariates, the school type variable was examined; Anatolian high school students have higher mathematics anxiety compared to general high school students. Moreover, male students have higher mathematics self-efficacy compared to female students. Similarly, students from higher SES are more likely to have higher mathematics self-efficacy compared to students from lower SES. Student's mathematics achievement was the most significant predictor of the mathematics self-efficacy, anxiety and self-concept factors. Students with high mathematics achievement were more likely to have higher mathematics self-efficacy and selfconcept and lower mathematics anxiety compared to students with low mathematics achievement. Finally, school's mathematics achievement was a significant predictor of only mathematics selfconcept. Students from schools that have higher mathematics achievement were more likely to have lower mathematics self-concept compared to students from schools that have lower mathematics achievement. 


\section{DISCUSSION and CONCLUSION}

In this study, the 2012 PISA Turkey data is considered to determine the big fish-little pond effect. The mathematics self-efficacy, self-concept and anxiety factors are examined to explain the relation of each of them with the gender, socioeconomic status, student's mathematics achievement, and school's mathematics achievement. Factor analyses' results support the construct validity of the student questionnaire's mathematics self-efficacy, anxiety and self-concept items. Two MIMIC models were analyzed and the patterns of association with covariates and affective factors were tested simultaneously.

Anatolian high school students have a higher mathematics self-efficacy and lower anxiety than do the general high school students according to the Model 1. However, when the student mathematics achievement and school mathematics achievement variables were inserted to the model, school type was not associated with mathematics self-efficacy. Moreover, Anatolian high school student's mathematics anxiety was higher than that of the general high school students in Model 2, which was opposite to the results of Model 1. Anatolian high school students that are admitted with high mathematics scores compare themselves with the classmates who have similar or higher mathematics scores may induce them to think that they are inadequate. As a result, they might have high mathematics anxiety.

In terms of gender, the male students' mathematics self-efficacy was higher than that of the female students for both models. However, male students' mathematics self-concept was higher than that of the female students at Model 1 whereas at Model 2, gender was not associated with mathematics self-concept.

While investigating the effect of SES, after inserting the variables of student's mathematics achievement and school's mathematics achievement into the Model 2, it was realized that SES was not associated with the mathematics anxiety and self-concept anymore. SES was a significant predictor of mathematics self-efficacy for both models.

The results show that students' mathematics achievement was the most powerful predictor of the mathematics self-efficacy, anxiety and self-concept factors.

Finally, school mathematics achievement was a significant predictor of mathematics self-concept. The identification of increase in school's mathematics achievement yields a decrease in the student's mathematics self-concept may be considered as the most important result of this study. It is straightforward that social comparison at the Anatolian high schools, which have a high school mathematics achievement, has an important role on the students' self-evaluation. Thus, this result provides evidence about not only the Anatolian high school students but also the high achieving school students experience big fish-little pond effect, which is consistent with the international results (Marsh et al., 2014; Marsh \& Hau, 2003; Nagengast \& Marsh, 2011; Seaton, Marsh, Yeung \& Craven, 2011). Besides, with the increase at school's mathematics achievement, there is a tendency for a decrease at student's mathematics self-efficacy and an increase at the anxiety. However, these results were not statistically meaningful as it was in the mathematics self-concept. This can be explained by items that evaluate mathematics self-efficacy having specific cognitive process which causes a higher correlation with the mathematics achievement. Another possible explanation is that students attending to schools that have higher mathematics achievement can evaluate themselves more precisely according to the students attending to the schools that have lower mathematics achievement about which type of mathematics items that they can answer correctly.

By 2014, in Turkey, the general high schools were converted to Anatolian high schools and thus all students were placed according to their high school entrance examination results to decrease the diversity among the quality of high schools and increase overall quality of the general high schools. Consequently, all high school students began to be grouped according to their academic capabilities. When the results of this study is evaluated by considering the new high school entrance system, the student's mathematics achievement is shown to be the most influential variable on the affective 
factors; however, especially, the school's mathematics achievement negative impact on the mathematics self-concept is undeniable.

In Turkey, there is a perception about attending a high school that admits students only with high test scores is the most beneficial thing for the students. In fact, rather than being a big fish in a small pond, attending a school with the students of a wide range of ability level and getting a good education might protect particularly the student's mathematics self-efficacy and also their mathematics anxiety and self-concept against the negative impacts of social comparison.

After the PISA study results, there has been a tendency in the world not to group the students according to their academic capabilities. On the contrary, in Turkey, the new high school entrance system makes the diversity of students' academic capabilities decrease among the schools. More studies should be required to discover the possible results of this new high school entrance system.

Author's note: The author gratefully acknowledges support from the TÜBİTAK and London School of Economics and would like to thank Professor Irini Moustaki for her valuable comments.

\section{REFERENCES}

Alcı, B., Erden, M., \& Baykal, A. (2010). Üniversite öğrencilerinin matematik başarıları ile algıladıkları problem çözme becerileri, özyeterlik algıları, bilişüstü özdüzenleme stratejileri ve ÖSS sayısal puanları arasındaki açıklayıcı ve yordayıcı ilişkiler örüntüsü. Boğaziçi Üniversitesi Ĕ̆itim Dergisi, 25(2), 5368.

Altun, F., \& Yazıcı, H. (2013). Ergenlerin benlik algılarının yordayıcıları olarak: akademik öz-yeterlik inancı ve akademik başarı. Kastamonu Ë̆itim Dergisi, 21(1), 145-156.

Ashcraft, M. H. (2002). Math anxiety: Personal, educational, and cognitive consequences. Current Directions in Psychological Science, 11(5), 181-185.

Baloglu, M., \& Kocak, R. (2006). A multivariate investigation of the differences in mathematics anxiety. Personality and Individual Differences, 40(7), 1325-1335.

Bandura, A. (1993). Perceived self-efficacy in cognitive development and functioning. Educational Psychologist, 28(2), 117-148.

Bong, M. (1998). Personal factors affecting the generality of academic self-efficacy judgments: Gender, ethnicity, and relative expertise. Journal of Experimental Education, 67, 315-331.

Cassady, J. C., \& Johnson, R. E. (2002). Cognitive test anxiety and academic performance. Contemporary Educational Psychology, 27(2), 270-295. doi:10.1006/ceps.2001.1094

Chiu, M. M., \& Xihua, Z. (2008). Family and motivation effects on mathematics achievement: Analyses of students in 41 countries. Learning and Instruction, 18, 321-336. doi:110.1016/j.learningstruc.2007.06.003

Cooper, S. E., \& Robinson, D. A. (1989). The influence of gender and anxiety on mathematics performance. Journal of College Student Development, 30(5), 459-461.

Festinger, L. (1954). A theory of social comparison processes. Human Relations, 7(2), 117-140.

Geist, E. (2010). The anti-anxiety curriculum: Combating math anxiety in the classroom. Journal of Instructional Psychology, 37(1), 24-31.

Hammouri, H. (2010). Attitudinal and motivational variables related to mathematics achievement in Jordan: findings from the TIMSS. Educational Research, 46(3), 241-257. doi:10.1080/0013188042000277313

Hattie, J. A. (1992). Self-concept. Hillsdale, NJ: Erlbaum.

Hembree, R. (1990). The nature, effects and relief of mathematics anxiety. Journal for Research in Mathematics Education, 21(1), 33-46.

Ho, E. S. (2009). Characteristics of East Asian learners: what we learned from PISA. Educational Research Journal, 24(2), 327-348.

Ho, H., Senturk, D., Lam, A. G., Zimmer, J. M., Hong, S., Okamoto, Y., Chiu, S., Nakazawa, Y., \& Wang, C. (2000). The affective and cognitive dimensions of math anxiety: A crossnational study. Journal for Research in Mathematics Education, 31(3), 362-379.

$\mathrm{Hu}$, L. T., \& Bentler, P. M. (1998). Fit indices in covariance structure modeling: Sensitivity to underparameterized model misspecification. Psychological Methods, 3(4), 424-453.

İş Güzel, Ç., \& Berberoğlu, G. (2010). Students' affective characteristics and their relation to mathematical literacy measures in the Programme for International Student Assessment (PISA) 2003. Eurasian Journal of Educational Research, 4, 93-113. 
Jain, S., \& Dowson, M. (2009). Mathematics anxiety as a function of multidimensional self-regulation and self-efficacy. Contemporary Educational Psychology, 34(3), 240-249.

Jöreskog, K. G., \& Sörbom, D. (1996). LISREL 8: User's reference guide. Chicago: Scientific Software International. Inc.

Jöreskog, K. G., \& Sörbom, D. (2006). LISREL 8.80 for Windows. Lincolnwood, IL: Scientific Software International, Inc.

Kurbanoğlu, N. I., \& Takunyacı, M. (2012). An investigation of the attitudes, anxieties and self-efficacy beliefs towards mathematics lessons high school students' in terms of gender, types of school, and students' grades. International Journal of Human Sciences, 9(1), 110-130.

Ma, X. (1999). A meta-analysis of the relationship between anxiety toward mathematics and achievement in mathematics. Journal for Research in Mathematics Education, 30(5), 520-540.

Marsh, H. W., Abduljabbar, A. S., Parker, P. D., Morin, A. J., Abdelfattah, F., \& Nagengast, B. (2014). The big-fish-little-pond effect in mathematics a cross-cultural comparison of US and Saudi Arabian TIMSS responses. Journal of Cross-Cultural Psychology, 45(5), 777-804.

Marsh, H. W., Chessor, D., Craven, R., \& Roche, L. (1995). The effects of gifted and talented programs on academic self-concept: The big fish strikes again. American Educational Research Journal, 32(2), 285-319.

Marsh, H. W., \& Hau, K. T. (2003). Big-Fish--Little-Pond effect on academic self-concept: A cross-cultural (26-country) test of the negative effects of academically selective schools. American Psychologist, 58(5), 364-376.

Marsh, H. W., Hau, K. T., Artelt, C., Baumert, J., \& Peschar, J. L. (2006). OECD's brief self-report measure of educational psychology's most useful affective constructs: Cross-cultural, psychometric comparisons across 25 countries. International Journal of Testing, 6(4), 311-360.

Marsh, H. W., Kong, C. K., \& Hau, K. T. (2000). Longitudinal multilevel models of the big-fish-little-pond effect on academic self-concept: Counterbalancing contrast and reflected-glory effects in Hong Kong schools. Journal of Personality and Social Psychology, 78(2), 337-349.

Marsh, H. W., Köller, O., \& Baumert, J. (2001). Reunification of East and West German school systems: Longitudinal multilevel modeling study of the big-fish-little-pond effect on academic self-concept. American Educational Research Journal, 38(2), 321-350.

Marsh, H. W., Trautwein, U., Lüdtke, O., Köller, O., \& Baumert, J. (2005). Academic self-concept, interest, grades, and standardized test scores: Reciprocal effects models of causal ordering. Child Development, 76(2), 397-416.

Marsh, H. W., Trautwein, U., Lüdtke, O., Baumert, J., \& Köller, O. (2007). The big-fish-little-pond effect: Persistent negative effects of selective high schools on self-concept after graduation. American Educational Research Journal, 44(3), 631-669.

McCarthy, J. M., \& Goffin, R. D. (2005). Selection test anxiety: Exploring tension and fear of failure across the sexes in simulated selection scenarios. International Journal of Selection and Assessment, 13(4), 282-295.

Nagengast, B., \& Marsh, H. W. (2011). The negative effect of school-average ability on science self-concept in the UK, UK countries and the world: The big-fish-little-pond-effect for PISA 2006. Educational Psychology, 31(5), 629-656. doi: 10.1080/01443420.2011.586416

OECD (2009). PISA data analysis manual SPSS (2 ${ }^{\text {nd }}$ edition). Paris: Publications.

OECD (2013). PISA 2012 Assessment and Analytical Framework: Mathematics, Reading, Science, Problem Solving and Financial Literacy, OECD Publishing. http://dx.doi.org/10.1787/9789264190511-en

Özel, M., Çağlak, S., \& Erdoğan, M. (2012). Are affective factors good predictor of science achievement? Examining the role of affective factors based on PISA 2006. Learning and Individual Differences, 24, 73-82. doi:10.1016/j.lindif.2012.09.006

Özgen, K., \& Bindak, R. (2011). Lise öğrencilerinin matematik okuryazarlığına yönelik öz-yeterlik inançlarının belirlenmesi. Kuram ve Uygulamada Eğitim Bilimleri, 11(2), 1073-1089.

Pajares, F. (1996). Self-efficacy beliefs in academic settings. Review of Educational Research, 66(4), 543-578.

Pajares, F., \& Graham, L. (1999). Self-efficacy, motivation constructs, and mathematics performance of entering middle school students. Contemporary Educational Psychology, 24(2), 124-139.

Pajares, F., \& Miller, M. D. (1994). Role of self-efficacy and self-concept beliefs in mathematical problem solving: A path analysis. Journal of Educational Psychology, 86(2), 193-203.

Reyes, L. H. (1984). Affective variables and mathematics education. The Elementary School Journal, 84(5), 558-581.

Schumacker, R. E., \& Lomax, R. G. (2010). A beginner's guide to structural equation modeling. Routledge NY. 
Seaton, M., Marsh, H. W., Yeung, A. S., \& Craven, R. (2011). The big fish down under: Examining moderators of the 'big-fish-little-pond'effect for Australia's high achievers. Australian Journal of Education, 55(2), 93-114.

Seipp, B. (1991). Anxiety and academic performance: A meta-analysis of findings. Anxiety Research, 4, $27-41$.

Taşdemir, C. (2012). Lise son sınıf öğrencilerinin matematik öz-yeterlik düzeylerinin bazı değişkenler açısından incelenmesi (Bitlis ili örneği). Karadeniz. Fen Bilimleri Dergisi, 2(6), 39-50.

Wigfield, A., \& Meece, J. L. (1988). Math anxiety in elementary and secondary school students. Journal of Educational Psychology, 80(2), 210-216.

Wilkins, J. L. (2004). Mathematics and science self-concept: An international investigation. The Journal of Experimental Education, 72(4), 331-346.

Wilkins, J. L. M., Zembylas, M., \& Travers, K. J. (2002). Investigating correlates of mathematics and science literacy in the final year of secondary school. In D. F Robataille \& A. E. Beaton (Eds.), Secondary analysis of the TIMSS data. Boston, MA: Kluwer Academic.

Wood, J. V. (1989). Theory and research concerning social comparisons of personal attributes. Psychological Bulletin, 106(2), 231-248.

Wu, M. L., \& Adams, R. J. (2002). Plausible values-why are they important. Paper presented at the International Objective Measurement Workshop, New Orleans, LA.

Zeidner, M., \& Schleyer, E. J. (1999). The big-fish-little-pond effect for academic self-concept, test anxiety, and school grades in gifted children. Contemporary Educational Psychology, 24(4), 305-329.

\section{UZUN ÖZET}

\section{Giriş}

Sosyal karşılaştırma teorisine göre, objektif standartların bulunmadı̆̆ 1 durumlarda, insanlar çevrelerinde bulunan diğer insanları temel alarak öz-değerlendirme yapmaktadır (Festinger, 1954). Okullar bu anlamda sosyal karşılaştırmanın en fazla yapıldığ 1 ortamlar olarak karşımıza çıkmaktadır. Akademik yeterliklerine göre gruplandırılarak eğitim gören öğrencilerler, farklı yetenek seviyesindeki öğrencilerle beraber eğitim görenlerden daha düşük benlik algısına sahip olmaktadır (Nagengast ve Marsh, 2011). Büyük balık-küçük göl etkisi olarak adlandırılan bu durum özellikle öğrencilerin başarılarına göre sınıflandırıldığı eğitim sistemlerinde görülmektedir (Ho, 2009).

Türkiye'de öğrenciler akademik başarılarına göre gruplandığından, büyük balık-küçük göl etkisinin okul seviyesinde yaşandığ 1 ve öğrencilerde oluşan farkındalığın, öğrencilerin matematik öz-yeterlik, kaygı ve benlik algılarını etkileyebileceği düşünülmektedir.

Bu çalışmanın amacı, Uluslararası Öğrenci Değerlendirme Programı (Programme for International Student Assessment, [PISA]) 2012 Türkiye verisi üzerinde Anadolu lisesi öğrencileriyle genel lise öğrencilerinin; cinsiyet, sosyoekonomik statü, öğrenci matematik başarısı, okul matematik başarısı değişkenlerinin matematik dersine yönelik öz-yeterlik, benlik ve kaygı değişkenleri arasındaki ilişkiyi açıklayarak büyük balık-küçük göl etkisini belirlemeye çalışmaktır.

\section{Yöntem}

Çalışma, PISA 2012 Türkiye verisinin bir yapısal eşitlik modellemesi olan MIMIC (Multiple Indicator Multiple Cause-Çoklu Gösterge ve Çoklu Neden) model ile analiz edilmesiyle gerçekleştirilmiştir. MIMIC modelde, her bir neden değişkeninin özgün etkisi diğer neden değişkenlerinin etkisi arındırılarak hesaplanabilmektedir.

Bu çalışmadaki veriler PISA 2012 uygulamasından elde edilmiştir. Çalışmada, öğrenci anketindeki okul türü, cinsiyet, sosyoekonomik statü, matematik öz-yeterlik, benlik ve kaygı ile ilgili maddeler kullanılmıştır. Türkiye verisinde matematik öz-yeterlik, kaygı ve benlik maddelerini cevaplayan, 36's1 Anadolu ve 52'si genel lise olmak üzere toplam 88 farklı liseden 771 öğrenci örnekleme alınmıştır.

Öncelikle açımlayıcı faktör analiziyle matematik dersine yönelik öz-yeterlik, kaygı ve benlik maddelerinin faktör yükleri belirlenmiş ve bu değişkenlere ait maddelerle doğrulayıcı faktör analizi yapılmıştır. Ardından MIMIC yapısal eşitlik modeli test edilerek Anadolu ve genel liseler için yol 
katsayıları karşılaştırılmıştır. İki MIMIC modeli analiz edilmiş ve bu analizlerle neden değişkenleri ve duyuşsal faktörler arasındaki örüntü eş zamanlı olarak test edilmiştir.

Model uyumunun değerlendirilmesinde RMSEA (Root Mean Squared Error of ApproximationOrtalama Karekök Hata Tahmini), CFI (Comparative Fit Index-Karşılaştırmalı Uyum İndeksi), NFI (Normed Fit Index-Normlaştırılmış Uyum İndeksi) ve GFI (Goodness of Fit Index-Uyum İyiliği İndeksi) uyum indeksleri kullanılmıştır. Analizler LISREL 8.8 (Jöreskog ve Sörbom, 2006) programı SIMPLIS komut dili kullanılarak gerçekleştirilmiştir.

Anketin ilgili maddelerinin öz değeri 1'den büyük üç faktörlü bir yapıya sahip olduğu belirlenmiş ve maddeler faktörler altında kümelenmelerine göre matematik benlik, öz-yeterlik ve kaygı olarak adlandırılmıştır. Bu üç faktör toplamda varyansın \%58,62'sini açıklamaktadır. Matematik benlik faktörüne dört madde $(\alpha=0,86)$, matematik öz-yeterlik faktörüne altı madde $(\alpha=0,74)$ ve matematik kaygı faktörüne dört madde yüklenmiştir $(\alpha=0,82)$. İkinci adımda, açımlayıcı faktör analizinden elde edilen sonuçlar, doğrulayıcı faktör analiziyle sınanmıştır. Doğrulayıcı faktör analiziyle ortaya çıkan üç boyutlu yapı kabul edilebilir bir model olup açımlayıcı faktör analiziyle ortaya çıkan yapının doğrulandığı söylenebilir. Üçüncü adımda, ölçme modeli doğrulayıcı faktör analizi ile sınandıktan sonra modele yapısal kısım ilave edilerek MIMIC model elde edilmiş ve parametreler kestirilmiştir.

MIMIC Model 1 ve 2 için hesaplanan veri uyumu kabul edilebilir seviyededir. Toplamda MIMIC Model 1 tarafından matematik öz-yeterlik, kaygı ve benlik faktörlerindeki değişkenliğin sırasıyla \%16's1, \%2'si ve \%2'si açıklanmıştır. MIMIC Model 2'de, Model 1'deki değişkenlere ilaveten ögrenci matematik başarısı ve okul matematik başarı ortalaması değişkenleri de modele eklenmiştir. MIMIC Model 2 tarafından matematik öz-yeterlik, kayg1 ve benlik faktörlerindeki değişkenliğin sırasıyla \%26'sı, \%12'si ve \%10'u açıklanmıştır.

\section{Sonuç ve Tartışma}

Bu çalışmada, 2012 PISA Türkiye verisi kullanılarak büyük balık-küçük göl etkisini belirlemek amacıyla, matematik öz-yeterlik, benlik ve kaygı faktörlerinin; cinsiyet, sosyoekonomik statü, ögrenci matematik başarısı ve okul matematik başarısı değişkenleriyle olan ilişkileri incelenmiştir.

Model 1'e göre Anadolu lisesi öğrencilerinin matematik dersine yönelik öz-yeterlikleri genel lise öğrencilerininkinden daha yüksek ve matematik kaygıları daha düşüktür. Bununla birlikte, modele öğrenci matematik başarısı ve okul matematik başarısı değişkenleri ilave edildiğinde okul türü matematik öz-yeterliği ile ilişkili değildir. Model 2'de Anadolu lisesi öğrencilerinin matematik kaygıları genel lise öğrencilerininkinden daha yüksektir. Bu sonuçlar Model 1'den elde edilen sonuçların tersidir. Yüksek matematik puanları ile Anadolu liselerine kabul edilen öğrencilerin, kendilerini benzer veya daha yüksek matematik başarısına sahip sınıf arkadaşlarıyla karşılaştırıyor olmaları bu öğrencilerin kendilerini yetersiz görmelerine sebep olmuş olabilir. Anadolu lisesi ögrencilerinin yüksek matematik kaygısı bu durumun bir sonucu olabilir.

Cinsiyet değişkeni incelendiğinde, her iki modelde de erkek öğrencilerin öz-yeterlik algılarının kız öğrencilerinkinden daha yüksek olduğu belirlenmiştir. Sadece, Model 1 için erkek öğrencilerin matematik benliği kız öğrencilerinkinden daha yüksek iken, Model 2'de cinsiyet ile matematik benlik algısı ilişkili değildir. Her iki model için de sosyoekonomik statü, matematik öz-yeterlik değişkeninin istatistiksel olarak anlamlı bir tahmin edicisidir. Sonuçlar göstermektedir ki öğrenci matematik başarıs1, matematik öz-yeterlik, benlik ve kayg1 değişkenlerinin en güçlü tahmin edicisidir. Son olarak, okul matematik başarısı matematik benlik algısının istatistiksel olarak anlamlı bir tahmin edicisidir. Bu çalışmanın en önemli bulgusu, okul matematik başarı ortalaması arttıkça öğrencilerin matematik benlik algılarının düşme eğiliminde olduğunun belirlenmesidir. Okul matematik başarı ortalamasının yüksek olduğu Anadolu liselerinde sosyal karşılaştırmanın öğrencilerin öz-değerlendirmesinde önemli bir rol oynadığı aşikardır. Bu durum, büyük balık-küçük göl etkisinin sadece Anadolu lisesi öğrencileri tarafindan değil, başarı ortalamasının yüksek olduğu liselere devam eden öğrenciler tarafından da yaşandığına dair kanıt sunmaktadır. Okulun matematik başarısı arttıkça öğrencilerin matematik öz-yeterlikleri düşme ve kaygıları artma eğiliminde olmakla 
beraber sonuçlar matematik benlik algısında olduğu gibi istatistiksel olarak anlamlı bir değişime işaret etmemektedir.

Türkiye'de 2014 yılı itibarıyla, liseler arasındaki kalite farklılıkların azaltılması ve genel liselerde verilen eğitimin seviyesinin artırılması amacıyla genel liseler, Anadolu liselerine dönüştürülmüş ve böylece tüm öğrenciler liselere giriş sınav sonuçlarına göre okullara yerleştirilmiştir. Sonuç olarak, öğrenciler yetenek seviyelerine göre bir arada olacak şekilde ayrıştırılmaya başlanmıştır. Türkiye'de ögrencilerin yüksek puanla öğrenci kabul eden bir okula devam etmesinin onlar için en iyisi olduğuna dair genel bir algı oluşmuştur. Aslında sınavla öğrenci kabul eden bir lisede küçük göldebüyük balık olmak yerine farklı yetenek seviyesindeki öğrencilerin birarada eğitim görmeleri, sosyal karşılaştırmanın öğrencilerin matematik öz-yeterlik algısı başta olmak üzere matematik kaygısı ve benlik algisı üzerindeki olumsuz etkisinden de koruyabilir. 